\title{
Martyna Szlufik
}

\section{Znaczenie i warunki rozwoju odnawialnych źródeł energii dla stanu środowiska naturalnego i zdrowia publicznego}

\begin{abstract}
Związek między pozyskiwaniem energii ze źródeł konwencjonalnych a degradacją środowiska naturalnego jest niezaprzeczalny. Autorka opisuje w artykule wpływ energii konwencjonalnej na dobra dziedzictwa przyrodniczego, takie jak Wielka Rafa Koralowa czy Arktyka, a także negatywne konsekwencje, jakie ona wywołuje dla zdrowia i życia człowieka. Drogą do naprawy obecnej sytuacji jest rozwój odnawialnych źródeł energii. Został on ukazany w aspekcie prawnym, przez przywołanie regulacji odnoszących się do ochrony zdrowia przyrody i człowieka. W artykule wskazane zostały przykłady państw i miast, które są w największym stopniu zasilane energią odnawialną. Autorka przekonuje, że korzystając $z$ energii odnawialnej możliwe jest tworzenie zdrowej i czystej przyszłości, do której „,bramę prawną” otwierają przywołane w tekście przepisy.
\end{abstract}

\section{Wstęp}

Wpływ stanu środowiska naturalnego na zdrowie człowieka nie ulega najmniejszym wątpliwościom. Zapoczątkowana w XIX wieku industrializacja na masową skalę stała się przyczyną chorób cywilizacyjnych. Obecny stan nauki i technologii pozwala na odwrócenie dawnego, niebezpiecznego powiązania. Dzisiejszy wysoki poziom innowacyjności i rozwój technologiczny idzie bowiem w parze z ekologią. Najlepszym dowodem słuszności tej tezy jest rozwój pozyskiwania energii ze źródeł odnawialnych. Warunkiem praktycznego jej wykorzystania jest by za nauką i techniką podążało prawo.

\section{Znaczenie rozwoju odnawialnych źródel energii dla ochrony środowiska}

Rozwój odnawialnych źródeł energii (OZE) jest zagadnieniem nie tylko ekonomicznym, ale także, a właściwie - przede wszystkim - związanym z ochroną środowiska naturalnego i zdrowia publicznego. Regulacje prawne tego obszaru są rozproszone w wielu aktach prawnych. Jednym $\mathrm{z}$ nich jest oczywiście Konstytucja $\mathrm{RP}^{1}$,

\footnotetext{
${ }^{1}$ Ustawa z 2.4.1997 r. - Konstytucja Rzeczypospolitej Polskiej, Dz. U. Nr 78, poz. 483 ze zm.
} 
której Preambuła zaczyna się słowami: „W trosce o byt i przyszłość naszej Ojczyzny (...””. Preambuła stanowi też o ,prawach i powinnościach wobec dobra wspólnego - Polski” oraz o tym, że obywatele są ,zobowiązani, by przekazać przyszłym pokoleniom wszystko, co cenne”. Wymieniona dalej „potrzeba współpracy ze wszystkimi krajami dla dobra Rodziny Ludzkiej” obliguje do podejmowania działań solidarnie z innymi państwami dla osiągnięcia wspólnego celu. Artykuł 68 ust. 1 Konstytucji stanowi wprost, że każdy ma prawo do ochrony zdrowia, natomiast zgodnie z ust. 4 tego artykułu „Władze publiczne są zobowiązane do (...) zapobiegania negatywnym dla zdrowia skutkom degradacji środowiska”. Ochrona środowiska (nierozerwalnie związana z OZE) jest gwarantowana także w art. 74 Konstytucji, który zobowiązuje władze publiczne do prowadzenia polityki zapewniającej bezpieczeństwo ekologiczne i nakłada na nie obowiązek ochrony środowiska, a także wsparcia takich działań u obywateli. Artykuł 82 stanowi z kolei o obowiązku troski o dobro wspólne, którym niewątpliwie jest przyroda. Każdy jest zobowiązany do dbałości o stan środowiska naturalnego, o czym wyraźnie stanowi art. 86 Konstytucji RP. „Niewątpliwie powinien [on - podkr. Autorki] być odczytywany łącznie z art. 5 dotyczącym zasady zrównoważonego rozwoju, art. 68 ust. 4 oraz art. 74 regulującymi obowiązek władz publicznych w zakresie ochrony środowiska i bezpieczeństwa ekologicznego. Oznacza to, że dbałość o stan środowiska i zapewnienie jego ochrony zgodnie z zasadą zrównoważonego rozwoju jest obowiązkiem nie tylko władz publicznych, kierunkiem polityki państwa, lecz także każdego człowieka i obywatela." ${ }^{2} \mathrm{Za}$ jego naruszenie grozi odpowiedzialność cywilna i karna. ${ }^{3}$ Warto podkreślić, że ,ustrojodawca wzmocnił rangę ochrony środowiska, ustanawiając ją - obok bezpieczeństwa lub porządku publicznego, ochrony zdrowia lub moralności publicznej czy wolności i praw innych osób - jedną z materialnych przesłanek ograniczenia konstytucyjnych wolności i praw człowieka i obywatela (art. 31 ust. 3 Konstytucji RP) ${ }^{4}$. Jeśli zatem będzie to konieczne w demokratycznym państwie prawnym, bez naruszenia jednocześnie istoty wolności lub prawa, ochrona środowiska dla dobra wspólnego, w imię interesu publicznego i dla realizacji ważnych zadań państwa, może uzasadniać ograniczenia innych konstytucyjnych wolności lub praw jednostki”"

\footnotetext{
${ }^{2}$ M. Haczkowska w: M.Haczkowska (red.), Komentarz do art. 86 Konstytucji Rzeczypospolitej Polskiej, 2014 Lex Omega.

${ }^{3}$ Tamże.

${ }^{4}$ Tamże.

${ }^{5}$ Tamże.
} 
Kolejnym ważnym aktem prawnym jest ustawa z 27.4.2001 r. - Prawo ochrony środowiska ${ }^{6}$. Artykuł 3 pkt 50 POŚ wprowadza bowiem do polskiego systemu prawnego pojęcie zrównoważonego rozwoju. Oznacza ono takie działania człowieka, które odbywają się z zachowaniem równowagi przyrodniczej i gwarantują możliwość zaspokajania potrzeb i korzystania z przyrody współczesnych i przyszłych pokoleń. Niezgodne z tą zasadą jest więc wyczerpywanie nieodnawianych zasobów oraz powodowanie nieodwracalnych zmian klimatu i jego konsekwencji przyrodniczych oraz niebezpiecznego zanieczyszczenia powietrza. Punkt 10 art. 50 POŚ stanowi o wykorzystywaniu ,najlepszych dostępnych technik", nawiązując niewątpliwie do technologii OZE, tak jak pkt 13b tegoż artykułu, który definiuje ochronę środowiska m.in. poprzez przeciwdziałanie zanieczyszczeniom (wskazać tu można choćby zanieczyszczenia powietrza powodowane pozyskiwaniem energii ze źródeł kopalnych, tzw. brudnej energii). Koncepcja zrównoważonego rozwoju jest obecna również w dalszych przepisach. Tak na przykład art. 71 POŚ stanowi o jej uwzględnieniu przy planach przestrzennego zagospodarowania oraz o konieczności zapobiegania zanieczyszczeniom. W kontekście art. 85 POŚ, który dotyczy ochrony powietrza, trudno o bardziej skuteczne metody jej realizacji, niż poprzez OZE.

Niedawno opublikowany raport $\mathrm{WHO}^{7}$ dotyczący najbardziej zanieczyszczonych miast na świecie wykazał, że na 50 miast UE pierwsze 33 miejsca zajmują miasta polskie. Tymczasem art. 91c POŚ stanowi, iż ,w przypadku przekroczenia poziomów dopuszczalnych (...) substancji w powietrzu występuje na znacznym obszarze kraju (...) minister właściwy do spraw środowiska może (podkr. Autorka) opracować krajowy program ochrony powietrza...”, zaś art. 91d POŚ stanowi, że przy „,przekroczeniu pułapu stężenia ekspozycji, osiągniecie krajowego celu redukcji narażenia powinno być jednym z wojewódzkich programów ochrony środowiska".

Akt wprowadza także zasady ochrony środowiska: komplementarności, zapobiegania, ponoszenia kosztów przez zanieczyszczającego, naprawy szkód oraz uwzględnienia ochrony środowiska w programach dotyczących wszelkich innych dziedzin (art. 5-8).

Ustawa z 23.3.2003 r. o planowaniu i zagospodarowaniu przestrzennym nakazuje $\mathrm{w}$ art. 10 ust. 1 uwzględniać $\mathrm{w}$ studium uwarunkowań i kierunków zagospodarowania przestrzennego gminy w szczególności wymogi ochrony środowiska i warunki i jakość życia mieszkańców ${ }^{8}$.

\footnotetext{
${ }^{6}$ Ustawa z 27.4.2001 r. Prawo ochrony środowiska, Dz. U. z 2017 r. poz. 519 ze zm., dalej jako POŚ.

${ }^{7}$ Polish city more polluted than Beijing, www.ft.com (dostęp 28.08.2017 r.).

${ }^{8}$ Ustawa 27.3.2003 r. o planowaniu i zagospodarowaniu przestrzennym, Dz. U. z 2017 r. poz. 1073 ze zm.
} 
Podobne do konstytucyjnych, choć bardziej rozbudowane regulacje zawiera prawo Unii Europejskiej. Zarówno w preambule Traktatu o Unii Europejskiej (TUE), jak i w jego art. 3 mowa jest o ochronie środowiska, a także wspieraniu postępu naukowo technicznego, którym niewątpliwie jest rozwój OZE. Artykuł 21 ust. 2 lit. d) TUE wskazuje na konieczność współpracy międzynarodowej w omawianej dziedzinie ${ }^{9}$. Z kolei Traktat o Funkcjonowaniu Unii Europejskiej (TfUE), poza zasadą zrównoważonego rozwoju (art. 11) art. 191 wymienia zasady oraz cele związane z ochroną środowiska, m.in. racjonalne wykorzystywanie jego zasobów, ochrona zdrowia ludzkiego. Ochronę ludzkiego zdrowia (także psychicznego), poprzez zapobieganie i usuwanie u źródeł zagrożeń nakazuje art. 168 oraz art.6 i 9TfUE. Dotyczący energetyki art. 194 ust. 1 lit. c) TfUE stanowi wprost o rozwoju odnawialnych form energii. ${ }^{10}$ Warto wspomnieć także o zobowiązaniu wynikającym $\mathrm{z}$ tzw. pakietu klimatyczno-energetycznego $3 \times 20^{11}$, zatwierdzonego w 2008 r., który zakłada wzrost udziału OZE na minimalnym poziomie 20\% (w przypadku Polski - 15\%). Polskę wiążą także międzynarodowe konwencje, takie jak Konwencja Wiedeńska z protokołami ${ }^{12}$, Protokół z Kioto ${ }^{13}$ oraz „Plan działania w zakresie energii do roku 2050"14, którego celem jest dekarbonizacja UE.

Deklaracja w sprawie Naturalnego Środowiska Człowieka wskazuje na potrzebę ochrony środowiska naturalnego, jego wpływie na zdrowie człowieka, konieczność wykorzystywania naukowych i technologicznych osiągnięć w celu rozwoju zgodnego z przyrodą, zabezpieczanie zasobów naturalnych i zakończenie emisji zanieczyszczeń. Wszystko to ma znaleźć odzwierciedlenie w prawie międzynarodowym i służyć całej ludzkości, wszystkim państwom bez podziałów i wyjątków ${ }^{15}$.

\footnotetext{
${ }^{9}$ TUE, DZ. U. z 2004 r. 90. 864/30 ze zm.

${ }^{10}$ TfUE, Dz. U. z 2004 r. 90. 864/2 ze zm.

${ }^{11} \mathrm{https}$ ://ec.europa.eu/clima/policies/strategies/2020_pl [dostęp 26.12.2017]

${ }^{12}$ Konwencja wiedeńska o ochronie warstwy ozonowej z 22.3.1985 r (ratyfikowana przez Polskę 25.6.1990 r), https:/www.mos.gov.pl/fileadmin/user_upload/srodowisko/konwencja_wiedenska.pdf [dostęp 26.12.2017]

${ }^{13}$ Protokół z Kioto do Ramowej Konwencji Narodów Zjednoczonych w sprawie zmian klimatu, sporządzony w Kioto 11.12.1997r, http://prawo.sejm.gov.pl/isap.nsf/download.xsp/WDU20052031684/O/D20051684.pdf [dostęp 26.12.2017]

${ }^{14}$ Plan działania w zakresie energii do roku 2050 z 15.12.2011, http://europa.eu/rapid/press-release_IP-111543 pl.htm (dostęp 26.12.2017)

${ }^{15}$ Declaration of the United Nations Conference on the Human Environment z 16 czerwca 1972, www.undocuments.net/unchedec.html (dostęp 13.08.2017).
} 


\section{Konsekwencje zanieczyszczonego powietrza dla zdrowia ludzi i przyrody}

Konsekwencją pozyskiwania energii ze źródeł konwencjonalnych jest zanieczyszczone powietrze. Ono z kolei wpływa w negatywny sposób na zdrowie człowieka, do tego stopnia, że Światowa Organizacja Zdrowia uznała je za główną środowiskową przyczynę nowotworów. Ich źródłem są spaliny samochodowe, emisje z elektrowni, gazy $\mathrm{z}$ rolnictwa i przemysłu, a także ogrzewanie prywatnych domów. Międzynarodowa Agencja Badań nad Rakiem (IARC) zaklasyfikowała zanieczyszczenia powietrza do tej samej kategorii co dym tytoniowy i promieniowanie UV. Dane Agencji pokazują, że smog każdego dnia zatruwa stopniowo, ale bardzo skutecznie ${ }^{16}$.

Choć wspomniany art. 91c)POŚ, w przypadku przekroczenia dopuszczalnego poziomu substancji w powietrzu na znacznym obszarze kraju, daje możliwość opracowania krajowego programu ochrony powietrza, który będzie dokumentem strategicznym ${ }^{17}$, nie jest to obowiązkiem ministra właściwego do spraw środowiska. „Wydaje się, że lepszym rozwiązaniem byłoby wskazanie, w jakich przypadkach jest to działanie obligatoryjne. W obecnej chwili opracowanie programów ma bowiem charakter uznaniowy, co (...) może doprowadzić do tego, że rozwiązanie to nie będzie efektywnie wykorzystywane w procesie ochrony powietrza", słusznie twierdzi Krzysztof Gruszewski ${ }^{18}$.

Zanieczyszczone powietrze to występowanie w atmosferze określonych zanieczyszczeń w ilościach, które negatywnie wpływają na zdrowie człowieka, środowisko oraz dziedzictwo kulturowe. Pył zawieszony jest tak lekki, że może unosić się w powietrzu, a jego cząstki są tak małe, że wnikają nie do płuc i krwioobiegu jak tlen. Skutki wchłonięcia pyłu zależą od jego składu chemicznego. Silnie trujący ozon powoduje korozję materiałów, budynków i żywych tkanek, u ludzi zapalenie płuc i oskrzeli. Niektóre z zanieczyszczeń uwalnianych $\mathrm{w}$ procesie spalania, takie jak metale ciężkie i trwałe zanieczyszczenia organiczne, gromadzą się w środowisku i w ten sposób przedostają się do ludzkiego łańcucha pokarmowego. W Europie około $80 \%$ benzenu, który niszczy materiał genetyczny komórek i prowadzi do nowotworów, pochodzi ze spalania paliwa przez pojazdy. Benzoa(a)piren uwalniany jest głównie podczas spalania drewna lub węgla w piecach domowych, ale także ze spalin samochodowych. Jest rakotwórczy, powoduje podrażnienia oczu, nosa, gardła

\footnotetext{
${ }^{16}$ Światowa Organizacja Zdrowia uznała zanieczyszczenia $w$ powietrzu, którym oddychamy, za główną, środowiskowa przyczynę raka, www.focus.pl(dostęp 17.08.2017).

${ }^{17}$ Ustawa z 27.4.2001 r. Prawo ochrony środowiska, Dz. U. z 2017 r. poz. 519 ze zm.

${ }^{18}$ K. Gruszewski, Komentarz do art. 91(c) ustawy - Prawo ochrony środowiska, Lex Omega.
} 
i oskrzeli. Dane wskazują, że ograniczenie poziomu $\mathrm{PM}_{2.5}$ (pył zawieszony o średnicy nie większej niż 2.5 mikrometra) do wytycznych WHO wydłużyłoby średnią długość życia ${ }^{19}$

Problem zanieczyszczeń pochodzących z transportu może być rozwiązany poprzez wspieranie rozwoju pojazdów ekologicznych, na które ukierunkowane są obecne działania UE. Dyrektywa 2014/94/UE ${ }^{20}$ ma na celu wsparcie zastosowania paliw alternatywnych w transporcie, w celu zmniejszenia uzależnienia państw członkowskich UE od importu ropy naftowej oraz do dekarbonizacji transportu i poprawy ekologiczności tego sektora.

Opracowany projekt ustawy o elektromobilności ma uregulować rynek paliw alternatywnych, określić zasady sprzedaży usługi ładowania pojazdów elektrycznych, działania podmiotów na rynku paliw alternatywnych, informowania konsumentów oraz przepisy techniczne dla tej infrastruktury oraz pozwolić na wprowadzenie w życie instrumentów wsparcia rozwoju transportu elektrycznego oraz gazu ziemnego. Jej założeniem jest rozwinięcie ekologicznego i innowacyjnego transportu oraz zmniejszenie uzależnienia sektora transportu od importu ropy naftowej ${ }^{21}$. Spowodowane głównie działalnością człowieka ocieplenie klimatu generuje ekstremalne zjawiska pogodowe, jak powodzie i fale upałów. Wg WHO do 2040 r. umieralność związana ze zmianami klimatu wzrośnie do 250000 zgonów rocznie na całym świecie, a do 2050 r. same tylko fale upałów będą przyczyną 120000 zgonów rocznie w $\mathrm{UE}^{22}$. Wysokie temperatury sprzyjają zanieczyszczeniu powietrza, zwłaszcza ozonem. Ekstremalne upały prowadzą do pożarów lasów, a te powodują zanieczyszczenie powietrza. Powodzie mogą przenosić zanieczyszczenia, chemikalia i ścieki, co prowadzić może do skażenia wody i gruntów. Wyższe temperatury i łagodniejsze zimy zapewniają rozprzestrzenianie się i niezakłócony rozwój owadów przenoszących choroby, głównie kleszczy i komarów. Zmiany sezonowe przyczyniają się do wzmożonej liczby ataków astmy, spadku zdolności produkcyjnej (a co za tym idzie wzrostu cen żywności) ${ }^{23}$. Zanieczyszczenia powietrza skracają życie aż o ok. $20 \%{ }^{24}$. Mimo licznych alarmów świata medycyny wciąż oddychamy smogiem. Taki stan rzeczy bez wątpienia stoi w sprzeczności z konstytucyjnym obowiązkiem władz publicznych zapobiegania negatywnym dla zdrowia

\footnotetext{
${ }^{19}$ Z każdym oddechem, eea.europa.eu (dostęp 17.08.2017).

${ }^{20}$ Dyrektywa Parlamentu Europejskiego i Rady 2014/94/UU z 22.10.2014 r. w sprawie rozwoju infrastruktury paliw alternatywnych, L 307/1, http://eur-lex.europa.eu/legal-content/PL/TXT/?uri=celex\%3A32014L0094 (dostęp 26.12.2017)

${ }^{21}$ Projekt ustawy o elektromobilności i paliwach alternatywnych, https://legislacja.rcl.gov.pl/projekt/12297850 (dostęp 7.10.2017).

${ }^{22}$ Zmiany klimatu a zdrowie człowieka, https://www.eea.europa.eu/pl/sygnal42y/sygnaly-2015/wywiad/zmianyklimatu-a-zdrowie-czlowieka (dostęp 18.08.2017).

${ }^{23}$ Życie w zmieniającym się klimacie, www.eea.europa.eu/signals (dostęp 17.08.2017).

${ }^{24}$ Wplyw zanieczyszczeń powietrza na ludzkie zdrowie, www.dolnoslaskialarmsmogowy.pl (dostęp 18.08.2017).
} 
konsekwencjom degradacji środowiska (art. 68 Konstytucji RP). Wynika z niego nie tylko obowiązek władz publicznych ochrony środowiska, ale przede wszystkim konstytucyjne prawo do życia w sprzyjającym środowisku. Dobrem chronionym wskazaną normą jest zdrowie ludzkie. Ustrojodawca dostrzega, że niemożliwe jest prawidłowe i skuteczne chronienie zdrowia w oderwaniu od działań na rzecz ochrony środowiska. Środowisko podlega ochronie jako istotny element wpływający na zdrowie i życie ludzkie ${ }^{25}$. Naukowcy z Uniwersytetu Stanforda dowiedli, że osoby spędzające więcej czasu w otoczeniu przyrody mają mniejsze skłonności do ruminacji (nawracających, przygnębiających myśli). Z badań wynika, że „kontakt z naturą pozwala zmniejszyć siłę negatywnych myśli”26.

Ustawodawca unijny wskazuje w art. 168 ust.1 TfUE, że „Działanie Unii, które uzupełnia polityki krajowe, nakierowane jest na poprawę zdrowia publicznego, zapobieganie chorobom i dolegliwościom ludzkim oraz usuwanie źródeł zagrożeń dla zdrowia fizycznego i psychicznego.",27

Jedną z największych ofiar zmian klimatu jest Wielka Rafa Koralowa. Jako obiekt światowego dziedzictwa UNESCO, zastosowanie znajdują do niej przepisy Konwencji W sprawie ochrony światowego dziedzictwa kulturalnego i naturalnego ${ }^{28}$. Zgodnie $\mathrm{z}$ art. 6 Konwencji państwa będące jej stronami uznają, w ochronie dziedzictwa powszechnego ma obowiązek współdziałać cała społeczność międzynarodowa.,Każde Państwo będące Stroną niniejszej Konwencji zobowiązuje się nie podejmować świadomie żadnych działań mogących wyrządzić bezpośrednio lub pośrednio szkodę dziedzictwu kulturalnemu i naturalnemu (...) znajdującemu się na terytorium innych Państw będących Stronami niniejszej Konwencji."29.

O zakazie uwalniania szkodliwej dla środowiska ilości toksycznych substancji i gorąca mówi szósta zasada Deklaracji Sztokholmskiej ${ }^{30}$.

Nieodpowiedzialne pozyskiwanie energii ze źródeł nieodnawialnych ma dewastujący wpływ także na Arktykę. Konsekwencje są skali globalnej, ponieważ oba mają decydujący wpływ na klimat na Ziemi, chłodzą go. Im mniejsza pokrywa śnieżna, tym mniej słonecznego gorąca pochłonie Ziemia, a zmianom ulegną także prądy oceaniczne. Arktyczny lód morski i znajdujące się pod nim morze są domem dla bogatego życia. Zanieczyszczenia z różnych

\footnotetext{
${ }^{25}$ M. Bartoszewicz, Komentarz do art. 68 Konstytucji Rzeczypospolitej Polskiej, Lex Omega.

${ }^{26}$ Natura: Najprostsze lekarstwo na zdrowie psychiczne, www.focus.pl (dostęp 18.08.2017).

${ }^{27}$ TfUE, Dz. U. z 2004 r. Nr 90 864/2 ze zm.

${ }^{28}$ Konwencja z 16.11 .1972 r. w sprawie ochrony światowego dziedzictwa kulturalnego i naturalnego, Dz.U. $1976 \mathrm{nr} 32$ poz. 190.

${ }^{29}$ Tamże.

${ }^{30}$ www.un-documents.net/unchedec.htm (dostęp 13.08.2017).
} 
stron świata, niesione przez wiatr do Arktyki, ze względu na tamtejsze niskie temperatury nie ulegają rozpadowi i pozostają w wodzie. Wchłaniane są przez zamieszkujące ją zwierzęta, a także lokalną ludność. Z kolei topniejący coraz wcześniej lód w pobliżu morza, na którym wylegują się foki, staje się zbyt cienki, by je utrzymać; w efekcie liczba fok spada, a co za tym idzie niedźwiedzie polarne głodują. Skala problemu jest na tyle olbrzymia, że niedźwiedziom grozi wyginięcie ${ }^{31}$.

Do działań ratujących Arktykę prawnie zobowiązuje m.in. art. 191 TfUE, który szczególny nacisk kładzie na zwalczanie zmian klimatu ${ }^{32}$. „Nie ulega również wątpliwości, że istnieje bezpośrednia zależność między bezpieczeństwem energetycznym a ochroną środowiska, ponieważ wśród wszystkich sektorów gospodarki sektor energetyczny jest jednym $\mathrm{z}$ najbardziej szkodliwych dla środowiska, zwłaszcza w zakresie emisji zanieczyszczeń do atmosfery.” 33 „W celu minimalizacji oddziaływania sektora energetycznego na środowisko, w ramach UE przyjęto wiele aktów prawa wtórnego, prowadzących do minimalizacji negatywnych skutków produkcji i konsumpcji energii, w tym odnoszących się do poprawy efektywności energetycznej, promocji odnawialnych źródeł energii, szerszego wykorzystania kogeneracji w elektroenergetyce czy bezpiecznego wykorzystania energii jądrowej. ${ }^{34, "}$ Konsekwencją topnienia lodowców jest podniesienie się poziomu oceanów, a przez to zalanie miliona rajskich wysp i wysepek oraz ogromnych obszarów państw przybrzeżnych.

Mimo argumentów przemawiających na korzyść OZE, ich przeciwnicy podnoszą argument ekonomiczny: instalacje OZE są bardzo kosztowne. Z drugiej strony jest to wydatek jednorazowy, który w przyszłości zwróci się z niemałą nadwyżką (nie tylko w sensie ekonomicznym). Jak podaje Europejska Agencja Środowiska (EEA), badając koszty związane z zanieczyszczeniem powietrza należy brać pod uwagę także koszty opieki medycznej, koszty wynikające $\mathrm{z}$ niższych plonów i szkód w określonych materiałach. Kierownik programu WHO dla Europy Bettina Menne alarmuje, że jeżeli nie zostaną podjęte działania, do 2050 r. fale upałów wywołane zmianami klimatu będą kosztować 150 mld $\mathrm{EUR}^{35}$. Wg WHO z powodu kosztów chorób i śmierci zanieczyszczone powietrze kosztuje gospodarki europejskie 1600 miliardów USD rocznie ${ }^{36}$.

\footnotetext{
${ }^{31}$ Arktyka - Czemu powinienem się troszczyć o Arktykę?, www.eea.europa.eu (dostęp 23.08.2017).

${ }^{32}$ TfUE, Dz. U. z 2004 r. 90. 864/2 ze zm.

${ }^{33}$ M. Nowacki, A. Przyborowska-Klimczak, Komentarz do art.191 Traktatu o funkcjonowaniu Unii Europejskiej.

${ }^{34}$ Tamże.

${ }^{35}$ Życie w zmieniajacym się klimacie, www.eea.europa.eu (dostęp 24.08.2017).

${ }^{36}$ Air pollution costs European economies USS 1.6 trillion...., www.euro.who.int (dostęp 24.08.2017 r.).
} 
Najlepiej jednak przekonywać na przykładach. Liderem zielonej energii jest Norwegia, a ogromną aktywnością na rynku OZE wykazują się Chiny, które są już obecnie największym na świecie producentem energii wiatrowej ${ }^{37}$. Bezsprzecznie milowy krok poczyniły Hawaje, ogłaszając przejście na wyłącznie energię odnawialną najpóźniej do 2045 r. ${ }^{38}$. Niemalże cała Kostaryka jest zasilana wyłącznie dzięki OZE ${ }^{39}$. W Europie stuprocentowym udziałem OZE w energetyce może pochwalić się Islandia ${ }^{40}$. Do miast zasilanych wyłącznie czystą energią w najbliższym czasie zaliczać się będą najprawdopodobniej Aspen, Kopenhaga, wyspa Bonuire, Monachium, San Diego, Isle of Wight, San Jose i San Francisco ${ }^{41}$.

\section{Zakończenie}

Pozyskiwanie energii ze źródeł odnawialnych pozwoli uratować dziedzictwo przyrodnicze przed konsekwencjami zmian klimatu, zdrowie publiczne przed postępującym zanieczyszczeniem powietrza oraz wypełnić międzynarodowe zobowiązania we wspólnym interesie i z korzyścią dla całej planety. Rolę ,prawniczego przewodnika” w tym obszarze odgrywa Deklaracja Narodów Zjednoczonych w Sprawie Naturalnego Środowiska Człowieka. Dokument ten stanowi podsumowanie zadań, jakie powinna wypełniać społeczność międzynarodowa. To środowisko daje pożywienie i możliwości intelektualnego, moralnego, społecznego i duchowego rozwoju. Możliwości człowieka do przekształcania jego otoczenia, jeśli będą użyte mądrze, mogą poprawić jakość życia. Źle zastosowane mogą wyrządzić nieobliczalne szkody środowisku i ludzkiemu istnieniu. Przez pełniejszą wiedzę i mądrzejsze działanie ludzkość może osiągnąć lepsze życie w lepszym środowisku. Dla osiągnięcia celu, jakim jest wolność w świecie natury, człowiek musi użyć wiedzy do tworzenia we współpracy $\mathrm{z}$ nią. Deklaracja wymaga $\mathrm{w}$ tej sferze współpracy międzynarodowej i działań międzynarodowych organizacji. Deklaracja nakłada na społeczeństwo odpowiedzialność za ochronę i poprawę środowiska dla obecnych i przyszłych pokoleń. Obliguje do zabezpieczenia naturalnych zasobów Ziemi poprzez ostrożne planowanie i zarządzanie nimi, nakazuje utrzymywanie i odnawianie zdolności planety do produkowania decydujących, żywotnych zasobów, uwzględnianie konserwacji natury

\footnotetext{
${ }^{37} 10$ najbardziej zielnych krajów świata, www.forbes.pl (dostęp 26.8.2017).

${ }^{38}$ Hawajski regulator zatwierdza plan an 100\% energii z OZE, gramwzielone.pl (dostęp 26.8 .2017 r.).

${ }^{39}$ W tym kraju prawie 100 proc. miksu energetycznego to OZE, gramwzielone.pl (dostęp 26.8.2017 r.).

${ }^{40}$ Kostaryka funkcjonuje w 100 procentach na odnawialnych ..., innpoland.pl (dostęp 26.8.2017 r.).

${ }^{41} 10$ miast o $100 \%$ udziale OZE w produkcji energii, blog.gsenergia.pl (dostęp 26.8.2017 r.).
} 
w planowaniu rozwoju ekonomicznego. Zakazuje wydzielania toksycznych substancji i uwalniania gorąca w ilościach przekraczających zdolność środowiska do zneutralizowania ich. Państwom rozwijającym nakazuje wziąć pod uwagę procesy ekologiczne. Zobowiązuje do pogodzenia konfliktu między potrzebami rozwoju i potrzebami ochrony środowiska. Podkreśla rolę i znaczenie instytucji państwowych oraz organizacji międzynarodowych, współpracujących w planowaniu, zarządzaniu i kontrolowaniu oddziaływania na środowisko oraz jego ochrony i poprawy. W duchu współpracy nakazuje zapobiegać wszelkim niesprzyjającym środowisku konsekwencjom lub eliminować je. Nauka i technika mają być wykorzystywane do rozwiązywania problemów środowiska, a ponadto technologie mu przyjazne powinny być dostępne dla państw rozwijających się. Państwa mają zawrzeć porozumienie odnośnie całkowitej eliminacji broni jądrowej i innej broni masowej zagłady ${ }^{42}$.

\section{Summary}

The connection between conventional energy and a degradation of the environment is undeniable. Author presents the impact of a conventional energy on the natural heritage such as a Great Barrier Reef or an Arctic and also its negative influence on human health and life. The way to repair the current situation is a renewable energy sources development. It is depicted in a legal aspect thought indication numerous regulations regarded to protection of health of the nature and a man. Article lists examples of countries and cities supplied by clean energy. Author believes that by using renewable energy, followed by mentioned legal regulations, healthy and clean future is possible.

\section{Martyna Szlufik}

Studentka trzeciego roku prawa na Wydziale Prawa i Administracji Uniwersytetu Kardynała Stefana Wyszyńskiego w Warszawie. Interesuje się ochroną środowiska, w szczególności regulacjami prawnymi tego obszaru, oraz prawami zwierząt.

\footnotetext{
${ }^{42}$ Declaration of the United Nations Conference on the Human Environment $\mathrm{z}$ 16.6.1972, www.undocuments.net/unchedec.htm (dostęp 8.10.2017 r.).
} 